\title{
The utilization of spent mushroom compost applied at different rates in tomato (Lycopersicon esculentum Mill.) seedling production
}

\author{
Mesude Ünal* \\ Kocaeli University, Arslanbey Vocational School 41285, Kartepe, Kocaeli, Turkey
}

\section{A B S T R A C T}

\begin{abstract}
The purpose of this research was to utilize spent mushroom compost as a seedling cultivation media in vegetative production and provide an alternative to the peat sources on the edge of extinction. Tomato (Lycopersicon esculentum Mill.) was used as a vegetative production material. In this research, 7 different growing media consisting of $100 \%$ peat, $100 \%$ spent mushroom compost and a mixture of peat + spent mushroom compost + perlite at varying rates were prepared. According to the results of the research, the values of hypocotyl length, seedling root length, shoot wet weight and root wet weight gave the best results the seedlings grown in $100 \%$ spent mushroom compost $(\mathrm{H} 7)$ the length of cotyledon contained $25 \%$ spent mushroom compost (H5), the width of cotyledon contained $25 \%$ spent mushroom compost (H3). Statistically, there was a difference between the mixtures of different cultivation media and the hypocotyl length at a level of $\mathrm{p}<0.05$. The best value of hypocotyl length was obtained as $48.00 \mathrm{~mm}$ from $\mathrm{H} 7$, implementation containing $100 \%$ spent mushroom compost. According to $\mathrm{H} 1$ media containing $100 \%$ peat, seedling root length increased in the media which spent mushroom compost was added into and a difference at a level of $p<0.05$ occurred between them. The addition of spent mushroom compost into the cultivation media can be said to have had a positive impact on the quality traits of tomato seedling.
\end{abstract}

Keywords: Peat; Seedling; Spent mushroom compost; Tomato

\section{INTRODUCTION}

The utilization of vegetal wastes such as stalks, straw, bran and molasses generated during the agricultural product harvest and industrial processing in the agricultural production again is an environmental approach (Akyüz and Kurbağ 2009). One of the wastes to be utilized is spent mushroom compost released during fungi culture. 2.5-3 kilos of wastes which cannot be used in mushroom production again remain from the production of 1 kilo of cultivated mushroom. Although fungi culture has a short past in Turkey, the amount of the mushrooms produced is increasing every year. According to the data in 2008, this amount is 26.526 tons (Şen and Yalçın 2010).

The utilization of tons of post-production waste materials as seedling cultivation media will be an alternative solution to the endangered peat resources. Peat is a natural organic matter which is about to extinct both in the world and in Turkey but is intensively used in plant production particularly in seedling cultivation. Birben et al. (1999) researched the impacts of 7 media prepared with spent mushroom compost, peat and perlite on Begonia (Begonia semperflorens) plant in their study. They declared that the mixtures of $50 \%$ spent mushroom compost $+50 \%$ peat and $25 \%$ spent mushroom compost $+50 \%$ peat $+25 \%$ perlite are the optimum media in terms of the physical properties of the media and plant development. Polat et al. (2004) researched the impacts of spent mushroom compost on the yield and quality in lettuce cultivation in their study. They stated that the implementation of 2 and 4 tons of synthetic spent mushroom compost per decare, which they applied in Autumn and Spring periods (0,1,2 and 4 ton/da), gave the best results in both periods in terms of yield. Benito et al. (2005) formed 6 different cultivation media by mixing peat, fallen leaves, sand and spent mushroom compost with the compost material they prepared with pruning wastes. They used grass (Lolium prenne L.) and cypress (Cupressus sempervirens L.) as test plants. As a result of the experiment, they determined that 
the mixture of $50 \%$ pruning waste compost $+25 \%$ peat $+25 \%$ spend mushroom compost and the mixture of $50 \%$ pruning waste compost $+50 \%$ spent mushroom compost could be optimum cultivation media. Medina et al. (2009) used spent mushroom compost as a seedling cultivation media instead of peat in their study. They experimented the effects of 12 media prepared with spent mushroom compost added in increasing doses on three types with different salt-sensitivity (tomato, pepper and courgette). They reported that spent mushroom compost blended at the rate of $75 \%$ could be used in tomato cultivation and the use of spent mushroom compost was an eco-friendly utilization way which made important contributions to vegetable production.

While the researches on the use of wastes as an alternative to peat are gaining momentum in the world, the studies to offer a solution to endangered peat resources through waste utilization are coming into prominence. In the study presented, it has been aimed to utilize spent mushroom compost in plant production and to develop alternative growth media to peat resources, which are about to extinct.

\section{MATERIALS AND METODS}

\section{Materials}

The study was conducted in the greenhouse of Arslanbey Vocational School of Kocaeli University. Randomized parcels were organized with 3 replications according to the experimental design. 7 growing media were prepared by mixing spent mushroom compost and peat at different rates. Growing media and mixing ratios were given in Table 1.

Samples of peat and spent mushroom compost made air-dried were mixed on a weight basis. In the experiment, mushroom production wastes released from the mushroom production facility at Arslanbey Vocational School being held in abeyance for 2 years and perlite and peat taken from a commercial concern were used.

Some chemical properties of the materials used in the experiment were given in Table 2. Test pots were left for incubation for 10 weeks in room conditions. The media

Table 1: Growing media and mixing ratios

\begin{tabular}{ll}
\hline Media & Mixing ratios \\
\hline $\mathrm{H} 1$ & Peat $(\% 100)$ \\
$\mathrm{H} 2$ & Spent mushroom compost $(\% 50)$ Peat $(\% 50)$ \\
$\mathrm{H} 3$ & Spent mushroom compost $(\% 25)$ Peat $(\% 75)$ \\
$\mathrm{H} 4$ & Spent mushroom compost $(\% 75)$ Peat $(\% 25)$ \\
$\mathrm{H} 5$ & Spent mushroom compost $(\% 25)$ Peat $(\% 65)$ Perlite $(\% 10)$ \\
$\mathrm{H} 6$ & Spent mushroom compost $(\% 70)$ Peat $(\% 20)$ Perlite $(\% 10)$ \\
$\mathrm{H} 7$ & Spent mushroom compost $(\% 100)$ \\
\hline
\end{tabular}

Emir. J. Food Agric • Vol $27 \bullet$ Issue $9 \bullet 2015$ were irrigated in field capacity throughout the experiment. In order to be able to see the impact of spent mushroom compost, additional fertilization was not made. At the end of the incubation period, 3 tomato seeds were planted in each pot. Certified tomato seeds were bought from a commercial company. The seed type H-2274 was used. During the first weeks of the experiment, hypocotyl length, cotyledon length and width were measured and recorded. At the end of the experiment, seedling length, seedling root length, shoot wet weight and root wet weight were determined.

\section{Methods of analysis}

The analysis of $\mathrm{pH}, \mathrm{EC}$, percentage of organic matter, total $\mathrm{N}$, available $\mathrm{P}$, exchangeable $\mathrm{Ca}, \mathrm{Mg}, \mathrm{K}$ and extractable $\mathrm{Fe}, \mathrm{Cu}, \mathrm{Zn}$ and $\mathrm{Mn}$ were determined in the peat and spent mushroom compost to be added to the mixture before the incubation. In the growth media available in each pot after the harvest of plants, $\mathrm{pH}$ and $\mathrm{EC}$ were determined with $\mathrm{pH}$ meter and EC meter (Richard 1954) in 1:2.5 media: distilled water suspension, spent mushroom compost $\mathrm{pH}$ and $\mathrm{EC}$ were determined 1:5 distilled water suspension. Organic matter with Walkle-Black wet combustion method (Jackson 1962), total N with Kjeldahl method (Bremmer 1965), available $\mathrm{P}$ with $\mathrm{NaHCO}_{3}$ extraction (Olsen et al. 1954), exchangeable $\mathrm{K}$ with ammonium acetate method in atomic absorption spectrophotometer (Knudsen et al. 1982) and exchangeable $\mathrm{Ca}$ and $\mathrm{Mg}$ with ammonium acetate method in atomic absorption spectrophotometer (Thomas 1982). $\mathrm{Fe}, \mathrm{Cu}, \mathrm{Zn}, \mathrm{Mn}$ extractable with DTPA were determined in an atomic absorption spectrophotometer (Lindsay and Norvell 1978). Heavy metals ( $\mathrm{Pb}, \mathrm{Cd}, \mathrm{Ni}, \mathrm{Cr}, \mathrm{Hg}$ ) extractable

Table 2: Some chemical properties of experiment materials used in the research

\begin{tabular}{lcc}
\hline Property & Peat & $\begin{array}{c}\text { Spent mushroom } \\
\text { compost }\end{array}$ \\
\hline $\mathrm{EC}$ & 1980,00 & 2950,00 \\
$\mathrm{pH}$ & 7,05 & 6,80 \\
$\mathrm{~N}(\%)$ & 1,50 & 1.84 \\
Available P $\left(\mathrm{mg} \mathrm{kg}^{-1}\right)$ & 13,79 & 206,84 \\
Exchangeable cations $\left(\mathrm{mg} \mathrm{kg}^{-1}\right)$ & & \\
$\mathrm{K}$ & 143,35 & 1072,25 \\
$\mathrm{Ca}$ & 1605,00 & 1803,37 \\
$\mathrm{Mg}$ & 680,75 & 570,01 \\
Organic matter $(\%)$ & 33,25 & 36,85 \\
$\mathrm{Available} \mathrm{heavy} \mathrm{metals}\left(\mathrm{mg} \mathrm{kg}^{-1}\right)$ & & \\
$\mathrm{Fe}$ & 93,28 & 36,17 \\
$\mathrm{Cu}$ & 1.42 & 3,98 \\
$\mathrm{Zn}$ & 1,26 & 35,56 \\
$\mathrm{Mn}$ & 11,71 & 39,76 \\
$\mathrm{~Pb}$ & 0,374 & 0,568 \\
$\mathrm{Cd}$ & 0,095 & 0,167 \\
$\mathrm{Ni}$ & 4,472 & 1,353 \\
$\mathrm{Cr}$ & 0,001 & 0,002 \\
$\mathrm{Hg}$ & 0,005 & 0,004 \\
\hline
\end{tabular}


with DTPA were extracted according to Lindsay and Norvell (1978) and results were determined in Inductively Coupled Plasma Spectrophotometer (ICP).

Statistical evaluations were made according to One WayAnova program. As a result of the variance analysis, different groups were determined by using Duncan test.

\section{RESULTS}

Some chemical properties of the growth media mixtures were given in Table 3. According to Table 3, pH was found to be between 6,94 and 7,28 EC was found to be between 1850,00 and 2800,00. As the amount of spent mushroom compost in the growth media increased, the salt contents of the media also increased. The percentage of the organic matter content in the media varied between 33,32 and 29,53. The maximum value was found in the H7 media, which contained $100 \%$ spent mushroom compost. The percentage of $\mathrm{N}$ content was between 1,82 and 1,47 . The medium with the highest nitrogen content was found in the $\mathrm{H} 7$ media, which contained $100 \%$ spent mushroom compost. Available $\mathrm{P}_{2} \mathrm{O}_{5}$ content is between 13,79 and 206,80. The lowest content was found in 100\% peat media and the highest content was found in 100\% spent mushroom compost media. Exchangeable $\mathrm{K}_{2} \mathrm{O}$ content of the media was found to be between 143,35 and $1072,00 \mathrm{mg} \mathrm{kg}^{-1}$, exchangeable Ca content was between 1600,73 and $1803,00 \mathrm{mg} \mathrm{kg}^{-1}$ and exchangeable $\mathrm{Mg}$ content was between 570,01 and $680,75 \mathrm{mg} \mathrm{kg}^{-1}$. $\mathrm{H} 7$ media, which contained $100 \%$ spent mushroom compost, gave the maximum value of $\mathrm{K}_{2} \mathrm{O}$ and $\mathrm{Ca}$ content compared to $\mathrm{H} 1$ media, which contained $100 \%$ peat. $\mathrm{Mg}$ content, however, had the minimum value in $\mathrm{H} 7$ media, which contained $100 \%$ spent mushroom compost. As the amount of the spent mushroom compost increased, $\mathrm{K}_{2} \mathrm{O}$ and $\mathrm{Ca}$ content of the media also increased.

Microelement contents of the growth media mixtures were given in Table 4. According to Table 4, available Fe value was between 92,85 and $33,53 \mathrm{mg} \mathrm{kg}^{-1}$. The maximum available Fe value was found in $\mathrm{H} 1$ media, which contained $100 \%$ peat, and the minimum value was found in $\mathrm{H} 7$ media, which contained $100 \%$ spent mushroom compost.
Fe content varied according to the amount of the peat in the media. Available $\mathrm{Cu}$ content of the media was found to be between 1,09 and 2,94 $\mathrm{mg} \mathrm{kg}^{-1}$ and available Zn content was found to be between 1,26 and 34,43. Spent mushroom compost caused an increase in the $\mathrm{Zn}$ value in the media. Available Mn content was between 11,51 and 38,50. H7 media, which contained $100 \%$ spent mushroom compost, gave the maximum Mn value.

The impacts of the implementation of growth media mixture on some quality traits of tomato seedlings were given in Table 5. According to Table 5, statistically, there is a difference between different growth media mixtures and hypocotyl lengths in $\mathrm{p}<0.05$ level. The maximum hypocotyl length value was obtained as $48,00 \mathrm{~mm}$ from the implementation of $\mathrm{H} 7$, which contained $100 \%$ spent mushroom compost, and the minimum hypocotyl length value was obtained as $41,33 \mathrm{~mm}$ from the implementation of $\mathrm{H} 3$, which contained $75 \%$ peat $+25 \%$ spent mushroom compost. The implementation of $\mathrm{H} 1$, which contained $100 \%$ peat and the implementations of $\mathrm{H} 2, \mathrm{H} 4, \mathrm{H} 5$, and H6, which contained peat and spent mushroom compost at different rates, statistically took place in the same letter group in terms of hypocotyl length value. The minimum value in cotyledon length was obtained as $23,50 \mathrm{~mm}$ from the application of $\mathrm{H} 1$, which contained $100 \%$ peat. The value of cotyledon length in the media with the addition of spent mushroom compost was higher compared to peat. The maximum values were obtained with $29,70 \mathrm{~mm}$ from the H5 media and as 29,13 mm from $\mathrm{H} 7$ media. The minimum value in the cotyledon width was obtained as $8,00 \mathrm{~mm}$ from $\mathrm{H} 1$ application and the maximum value as 10,76 from $\mathrm{H} 3$ application. According to the values of seedling lengths in Table 5 , the addition of spent mushroom compost into the media increased the seedling length values compared to $\mathrm{H} 1$, which contained $100 \%$ peat. The minimum value was obtained as $10,60 \mathrm{~cm}$ from $\mathrm{H} 1$ media, which contained $100 \%$ peat, and the maximum value as $22,52 \mathrm{~cm}$ from $\mathrm{H} 7$ media, which contained $100 \%$ spent mushroom compost. Statistically, there is no difference among $\mathrm{H} 2, \mathrm{H} 3, \mathrm{H} 4, \mathrm{H} 5, \mathrm{H} 6$ and $\mathrm{H} 7$ media. Seedling root lengths showed a parallel development with seedling lengths. The minimum seedling root length value was obtained as $8,55 \mathrm{~cm}$ from $\mathrm{H} 1$ media and the maximum

Table 3: Some chemical properties growing media mixtures

\begin{tabular}{|c|c|c|c|c|c|c|c|c|}
\hline Growing media & $\mathrm{pH}$ & EC & OM (\%) & N (\%) & $\mathrm{P}_{2} \mathrm{O}_{5}\left(\mathrm{mg} \mathrm{kg}^{-1}\right)$ & $\mathrm{K}_{2} \mathrm{O}\left(\mathrm{mg} \mathrm{kg}^{-1}\right)$ & $\mathrm{Ca}\left(\mathrm{mg} \mathrm{kg}{ }^{-1}\right)$ & $M g\left(\mathrm{mg} \mathrm{kg}^{-1}\right)$ \\
\hline $\mathrm{H} 1$ & 7,28 & 1850,00 & 29,53 & 1,47 & 13,79 & 143,35 & 1605,00 & 680,75 \\
\hline $\mathrm{H} 2$ & 7,05 & 1951,00 & 31,12 & 1,67 & 164,91 & 580,42 & 1720,00 & 640,30 \\
\hline H3 & 7,09 & 1900,00 & 31,52 & 1,55 & 133,48 & 390,73 & 1660,25 & 610,82 \\
\hline $\mathrm{H} 4$ & 7,09 & 2242,00 & 32,50 & 1,80 & 177,62 & 780,65 & 1745,00 & 595,40 \\
\hline H5 & 6,94 & 2025,00 & 30,17 & 1,61 & 123,83 & 320,55 & 1600,73 & 600,45 \\
\hline $\mathrm{H} 6$ & 7,08 & 2090,00 & 31,42 & 1,75 & 181,53 & 678,62 & 1700,55 & 580,00 \\
\hline $\mathrm{H} 7$ & 7,00 & 2800,00 & 33,32 & 1,82 & 206,80 & 1072,00 & 1803,00 & 570,01 \\
\hline
\end{tabular}


seedling root length value as $21,35 \mathrm{~cm}$ from $\mathrm{H} 7$ media. Statistically, H3, H4, H5 and H6 are in the same letter group. The addition of spent mushroom compost into the media caused a difference in the seedling root length in $\mathrm{p}<0.05$ level compared to $\mathrm{H} 1$, which contained $100 \%$ peat.

The minimum value in the shoot wet weight and root wet weight were obtained from $\mathrm{H} 1$ media, which contained $100 \%$ peat, and the maximum value from $\mathrm{H} 7$ media, which contained $100 \%$ spent mushroom compost. Statistical assessment support the results. The minimum shoot wet weight value is $4,11 \mathrm{~g}$ and the maximum value is $14,20 \mathrm{~g}$. Spent mushroom compost admixture increased the shoot wet weight in the media in comparison with $100 \%$ peat media. The minimum root wet weight value was $0,05 \mathrm{~g}$ and the maximum value is $1,54 \mathrm{~g}$. The root wet weight increased in the media that contained spent mushroom compost compared to the media that contained $100 \%$ peat.

\section{DISCUSSION}

When we examine some chemical properties of growth media mixtures, $\mathrm{pH}$ value is neutral according to Richards (1954), Ülgen and Yurtsever (1974). The $\mathrm{pH}$ value of the medium can be said to be suitable to grow seedling. $6,5-7,5 \mathrm{pH}$ is the optimum value for the availability of various macro and micro nutrients (Aktaş 2004). It is reported that in high $\mathrm{pH}$ values, root development is affected. (Güness et al. 2004). The EC value of the media increases with the addition of spent mushroom compost, but there are no salinity issues in the media. Kirven (1986) reported that EC value in growth media should be

Table 4: Growing media mixtures contents of micro elements

\begin{tabular}{lcccc}
$\begin{array}{l}\text { Growing } \\
\text { media }\end{array}$ & $\begin{array}{c}\mathbf{F e} \\
\left(\mathbf{m g ~ k g}^{-1}\right)\end{array}$ & $\begin{array}{c}\mathrm{Cu} \\
\left(\mathbf{m g ~ k g}^{-1}\right)\end{array}$ & $\begin{array}{c}\mathbf{Z n} \\
\left(\mathbf{m g ~ k g}^{-1}\right)\end{array}$ & $\begin{array}{c}\mathbf{M n} \\
\left(\mathbf{m g ~ k g}^{-1}\right)\end{array}$ \\
\hline H1 & 92,85 & 1,09 & 1,26 & 11,51 \\
H2 & 66,73 & 1,86 & 34,08 & 26,24 \\
H3 & 83,46 & 1,70 & 36,11 & 20,11 \\
H4 & 58,20 & 2,93 & 37,00 & 35,01 \\
H5 & 85,96 & 1,73 & 31,47 & 31,90 \\
H6 & 47,31 & 2,53 & 34,44 & 37,31 \\
H7 & 33,53 & 2,94 & 34,43 & 38,50 \\
\hline
\end{tabular}

2-4 dS/m. Salinity is one of the main problems in spent mushroom compost. Waiting the compost used in the research in open area for two years might have reduced the salt content. According to Günay (1995), waiting the compost piled up in rainy regions for one or two years enables the self-washing of the salt and toxic substances. The addition of spent mushroom compost increased the organic matter and nitrogen content of the media compared to $100 \%$ peat media. While the amount of organic matter in $100 \%$ peat media was $29,53 \%$, the amount of organic matter in the media that contained $50 \%$ peat $+50 \%$ spent mushroom compost was $31,12 \%$. While the percentage of $\mathrm{N}$ in $100 \%$ peat media was 1,47 , the percentage of $\mathrm{N}$ in $50 \%$ peat $+50 \%$ spent mushroom compost media was 1,67. Baran et al. (1995) reported that organic matter and nitrogen values of spent mushroom compost were high in their study. Available P content in $\mathrm{H} 7$ media was very high according to FAO 1990 data. In the study Günay et al. (1996) carried out, the results of available P content of spent mushroom compost are similar to ours. In some studies, exchangeable $\mathrm{K}, \mathrm{Ca}$ and $\mathrm{Mg}$ values of the media include different results (Abak and Çelikel 1996, Demirtaş et al. 2007, Polat et al. 2009). Topçuoğlu et al. (2004) made chemical analyses of the spent mushroom compost, they obtained from mushroom enterprises and reported that the properties examined in the samples were different in statistical terms. The difference in nutrient content might result from the different applications carried out during the compost production. Chemical fertilizers used in compost production and their quantities can affect the results of the study. When we examine the micro element contents of the media, $\mathrm{Cu}$ and $\mathrm{Mn}$ are in sufficient levels, Fe is high and $\mathrm{Zn}$ is to excess (Follet 1969, Lindsay and Norvell 1978, FAO 1990). The addition of spent mushroom compost increased the $\mathrm{Cu}, \mathrm{Zn}$ and $\mathrm{Mn}$ contents of the media. Fe content of the media, however, decreased with the addition of spent mushroom compost.

The addition of spent mushroom compost into the growth media had a positive impact on the quality properties of tomato seedlings. The values of hypocotyl length, seedling length, seedling root length, shoot fresh weight and root fresh weight gave the best results in the seedlings grown

Table 5: Tomato seedling some quality values as affected by growing media used

\begin{tabular}{lccccccc}
\hline $\begin{array}{l}\text { Growing } \\
\text { media }\end{array}$ & $\begin{array}{c}\text { Hypocotyl } \\
\text { height }(\mathbf{m m})\end{array}$ & $\begin{array}{c}\text { Cotyledon } \\
\text { length }(\mathbf{m m})\end{array}$ & $\begin{array}{c}\text { Cotyledon } \\
\text { width }(\mathbf{m m})\end{array}$ & $\begin{array}{c}\text { Seedling } \\
\text { height }(\mathbf{c m})\end{array}$ & $\begin{array}{c}\text { Seedling root } \\
\text { length }(\mathbf{c m})\end{array}$ & $\begin{array}{c}\text { Fresh shoot } \\
\text { weight }(\mathbf{g})\end{array}$ & $\begin{array}{c}\text { Fresh root } \\
\text { weight }(\mathbf{g})\end{array}$ \\
\hline $\mathrm{H} 1$ & $42,66 \pm 0,4 \mathrm{ab}$ & $23,50 \pm 1,0 \mathrm{a}$ & $8,00 \pm 0,8 \mathrm{a}$ & $10,60 \pm 0,2 \mathrm{a}$ & $8,55 \pm 0,5 \mathrm{a}$ & $4,11 \pm 0,8 \mathrm{a}$ & $0,05 \pm 0,01 \mathrm{a}$ \\
$\mathrm{H} 2$ & $42,16 \pm 0,9 \mathrm{ab}$ & $25,00 \pm 3,7 \mathrm{ab}$ & $9,53 \pm 0,5 \mathrm{ab}$ & $19,12 \pm 0,8 \mathrm{~b}$ & $17,00 \pm 1,8 \mathrm{~b}$ & $8,52 \pm 0,9 \mathrm{~b}$ & $0,36 \pm 0,09 \mathrm{~b}$ \\
$\mathrm{H} 3$ & $41,33 \pm 2,8 \mathrm{a}$ & $26,43 \pm 2,8 \mathrm{ab}$ & $10,76 \pm 1,9 \mathrm{~b}$ & $21,30 \pm 2,9 \mathrm{~b}$ & $18,42 \pm 0,7 \mathrm{bc}$ & $10,23 \pm 0,3 \mathrm{bc}$ & $0,50 \pm 0,08 \mathrm{~b}$ \\
$\mathrm{H} 4$ & $43,33 \pm 1,2 \mathrm{ab}$ & $26,50 \pm 1,8 \mathrm{ab}$ & $10,30 \pm 0,5 \mathrm{ab}$ & $21,52 \pm 1,3 \mathrm{~b}$ & $17,33 \pm 1,6 \mathrm{bc}$ & $11,40 \pm 0,7 \mathrm{~cd}$ & $0,48 \pm 0,06 \mathrm{~b}$ \\
$\mathrm{H} 5$ & $45,00 \pm 2,1 \mathrm{ab}$ & $29,70 \pm 0,8 \mathrm{~b}$ & $10,45 \pm 0,4 \mathrm{ab}$ & $21,10 \pm 2,0 \mathrm{~b}$ & $18,50 \pm 1,8 \mathrm{bc}$ & $12,55 \pm 1,4 \mathrm{de}$ & $0,85 \pm 0,1 \mathrm{c}$ \\
$\mathrm{H} 6$ & $46,20 \pm 1,2 \mathrm{ab}$ & $28,60 \pm 2,5 \mathrm{ab}$ & $9,70 \pm 1,2 \mathrm{ab}$ & $20,35 \pm 1,5 \mathrm{~b}$ & $20,75 \pm 2,5 \mathrm{bc}$ & $11,28 \pm 0,6 \mathrm{~cd}$ & $1,35 \pm 0,14 \mathrm{~d}$ \\
$\mathrm{H} 7$ & $48,00 \pm 5,7 \mathrm{~b}$ & $29,13 \pm 3,4 \mathrm{ab}$ & $10,36 \pm 0,8 \mathrm{ab}$ & $22,52 \pm 3,1 \mathrm{~b}$ & $21,35 \pm 2,5 \mathrm{c}$ & $14,20 \pm 1,2 \mathrm{e}$ & $1,54 \pm 0,04 \mathrm{e}$ \\
\hline
\end{tabular}

Means with different letters in the same row, $p<0.05$ level, there is a difference and SD: Standard deviation 
in $100 \%$ spent mushroom compost (H7). The results are similar to the ones in the study Günay et al. carried out (1996). They reported that the media consisting of spent mushroom compost gave the best results in the development of some ornamental plants.

Dura et al. (2000) stated that the use of only spent mushroom compost in pepper was not as effective as classical compost material. Different results might stem from the chemical composition and salt contents of the spent mushroom compost. Polat et al. (2009) reported that spent mushroom compost kept waiting for minimum 6 months gave positive results in the growth and yield of cucumber (Cucumis sativus L.). H5 media which $25 \%$ spent mushroom compost contained the length of cotyledon, $\mathrm{H} 3$ media which $25 \%$ spent mushroom compost contained the width of cotyledon gave the best results. Özgüven (1998) stated that the use of spent mushroom compost in strawberry cultivation could be an alternative to the farm manure, which is expensive.

Pekşen and Günay (2009) cultivated mushrooms in organic media and reported that the mixture of tea waste and wheat stem brought to a successful conclusion and it could be used as an alternative media. The addition of spent mushroom compost into the growth media was reported to result in successful in lettuce cultivation by Polat et al. (2004), in the germination and growth of garden plants by Medina and his friends (2009) and in chrysanthemum production by Çiçek et al. (2012).

Birben et al. (1999) examined the physical and chemical properties of the growth media mixtures and reported that spent mushroom compost could be used at the rates of up to $50 \%$. Benito et al. (2005) prepared different growth media and recommended M5 and M6 media, which contained $25 \%$ and $50 \%$ spend mushroom compost, as the rates of $\mathrm{N}, \mathrm{P}_{2} \mathrm{O}_{5}$ and $\mathrm{K}_{2} 0$ might affect the plant growth.

In conclusion, spent mushroom compost can be used as seedling cultivation media or can be added into the media at certain rates. In this research, spent mushroom compost positive impact, seedling development. However, salt content is a restrictive factor in the determination of the amount of use. Söchtig and Grabbe (1995) emphasized the importance of the salt content. Erkel (1990) reported that waiting the compost in the open for 1-1.5 years and reutilizing it after being washed 5-6 times was appropriate.

Utilization of spent mushroom compost in seedling growth media is an alternative to the other growth media, which are about to extinct and expensive. Environmental issues are evident. Solutions should be created in order to feed the increasing population without causing ecosystem degradation and researchs on re-utilization should be diversified and increased.

\section{ACKNOWLEDGEMENT}

This work was for laboratory support wish to thank to Republic of Turkey Ministry of food, agriculture and livestock Kocaeli Provincial Directorate and Food Control Laboratory Kocaeli Provincial Directorate.

\section{Authors' contributions}

M.Ü. designed the study, was involved in overall planning and wrote the article.

\section{REFERENCES}

Abak, K. and G. Çelikel. 1996. Mushroom compost use in soilless cultivation in greenhouses. Turkey 5. Edible Mushroom Congress. 5-7 November. Atatürk Central Horticultural Research Institute, Yalova, Pp. 249-258.

Aktaş, M. 2004. Nutritional deficiencies in plants and diagnose. Turkey 3. National Fertilizer Congress, Agri-IndustryEnvironment 11-13 October. Tokat, Pp. 1118-1186.

Akyüz, M. and S. Kırbağ. 2009. Evaluation of some agricultural and industrial wastes as a compost for the cultivation of Pleurotus spp. Ekoloji. 18: 27-31.

aran, A., G. Çaycı and A. İnal. 1995. Some physical and chemical properties of different agricultural wastes. Pamukkale Univ. Muh Bilim. Derg. 1: 169-172.

Benito, M., A. Masaguer, R. De Antonio and A. Moliner. 2005. Use of pruning waste compost as a component in soilless growing media. Bioresour Technol. 96: 597-603.

Birben, H., G. Çaycı and C. Kütük. 1999. The effects of spent mushroom compost on growth of begonia (Begonia semperflorens) plant. Turkey III. National Horticulture Congress. September 14-17. Ankara, Pp. 187-191.

Bremner, J. M. 1965. Methods of soil analysis. Part 2. In: Chemical and Microbiological Properties. Vol. 9. American Society of Agronomy. Inc. Agronomy Series, Madison, Wisconsin, USA, p. 400.

Çiçek, N., C. Kütük, Y. Kaşko Arıcı and B. C. Bilgili. 2012. Effect of different growing media prepared with spent mushroom compost on growth parameters of chrysanthemum (Chrysanthemum morifolium) plant. Tarım Bilimleri Araştırma Dergisi. 5: 68-75.

Demirtaş, I., N. Arı, A. Arpacıoğlu, H. Kaya and C. Özkan. 2007. Different organic fertilizer chemical properties. The effect of spent mushroom compost use on some soil properties and yield in greenhouse tomato cultivation. Turkey V. National Horticulture Congress. Erzurum. Pp. 220-223.

Dura, S., Z. Sakınç and A. Günay. 2000. A research possibilities of using on spent mushroom compost seedling cultivation. Turkey VI. Edible Mushroom Congress and Posters. II. Edition. Eylül Bergama-İzmir, Pp. 20-22.

Erkel, İ. 1980. Possibilities of using a mix of cover material. Turkey III. Edible Mushroom Congress. Yalova, Pp.85-91.

FAO. 1990. Micronutrient, Assessment at the Country Level; An International Study. FAO Soil Bulletin by Sillanpaa, Rome.

Follet, R. H. 1969. Zn. Fe. Mn and Cu in Colorado Soils. Ph. D. Dissertation. Colorado. State University. 
Günay, A. 1995. Mushroom Cultivation. 11th ed. Illke Bookstore Publications, Ankara, p. 469.

Günay, A., M. E. İlbay, K. Demir and E. Barış. 1996. Possibilities of using spent mushroom compost in growing of some ornamental plant. (Petunia hybridia, Ageratum mexicanum, Tagetes erecta). Turkey 5. Edible Mushroom Congress. 5-7 November. Atatürk Central Horticultural Research Institute, Yalova, Pp. 240-248.

Güneş, A., M. Alpaslan and A. İnal. 2004. Plant nutrition and fertilizer. Ankara Universty Faculty of Agriculture. Issue Number: 1539, Course Book: 492. p. 576.

Jackson, M. L. 1962. Soil Chemical Analysis. Prentice Hall, Inc., Cliffs, USA.

Kirven, D. M. 1986. "An Industry Viewpoint: Horticultural Testing is Your Language Confusing" Proceeding of the Sym. Interpretation of Extraction and Nutrient Determination Procedures for Organic Potting Ubstrates, Pp. 215-217.

Knudsen, D.,G. A. Peterson and P. F. Pratt. 1982. Lithium, sodium and potassium. Methods of soil analysis part 2. Chemical and Microbiological Properties. Agronomy Monograph. No. 9. 2nd ed. ASA-SSSA Madison Wisconsin USA.

Lindsay, W. L. and W. A. Norvell. 1978. Development of a DTPA soil test for zinc, iron, manganese and copper. Soil Sci. Soc. Am. Proc. 42: 421-428.

Medina, E., C. Paredes, M. D. Perez-Murcia, M. A. Bustamante and R. Moral. 2009. Spent mushroom substrates as component of growing media for germination and growth of horticultural plants. Bioresour. Technol. 100: 4227-4232.

Olsen, S. R., V. Cole, F. S. Watanabe and L. A. Dean. 1954. Estimation of Available Phosphorus in Soils by Extraction with Sodium Bicarbonate. Vol. 939. U. S. Department of Agriculture, Washington, D.C.
Özgüven, A. I. 1998. The opportunities of using mushroom compost waste in strawberry growing. Turk. J. Agric. Forestry. 22: 601-607.

Pekşen, A. and A. Günay. 2009. Use of substrates prepared by the mixture of tea waste and wheat straw in Agaricus bisporus (L.) sing cultivation. Ekoloji, 19: 48-54.

Polat, E., A. N. Onus and H. Demir. 2004. The effects of spent mushroom compost on yield and quality in lettuce growing. Akdeniz Univ. J. Fac Agric. 17: 149-154.

Polat, E., H. İ. Uzun, B. Topçuoğlu, K. Önal, A. N. Onus and M. Karaca. 2009. Effects of spent mushroom compost on quality and productivity of cucumber (Cucumis sativus L.) grown in greenhouses. Afr. J. Biotechnol. 8: 176-180.

Richards, L. A. 1954. Diagnosis and imporvment of saline and alkaline soils. U.S.D.A. Handbook, No: 60 , USA.

Söchtig, H. and K. Grabbe. 1995. The production and utilization of organic-mineral fertilizer from spent mushroom compost. Sci Cultivation of Edible Fungi. 2: 907-915.

Şen, S. and M. Yalçın. 2010. The World and Turkey cultivated mushroom and improved. III. National karadeniz forestry congress 20-22. Mayıs, 3: 1208-1216.

Thomas, G. W. 1982. Exchangeable cations. Chemical and microbiological properties. Agronomy monograph No. 9. $2^{\text {nd }}$ ed. ASASSSA, Madison, Wisconsin USA. Pp. 159-165.

Topçuoğlu, B., N. Arı and M. K. Önal. 2004. Chemical characteristics and mineral contents of spent mushroom compost in Korkuteli district. Turkey 3. National Fertilizer Congress, Agric- IndustryEnvironment. 11-13 October. Tokat, Pp.787-792.

Ülgen, N. and N. Yurtsever. 1974. Turkey fertilizer and fertilizing guide. Soil and Fertilizer Research Institute, Technical Publication No. 28, Ankara. 